\title{
Research on the Improvement Path of Agricultural Supply Quality Based on Pre-control under the "Internet +"
}

\author{
Hua Liu ${ }^{1, a}$, Lian-cun Zuo ${ }^{1}$, Jin-yu Chen ${ }^{1}$ \\ ${ }^{1}$ Guangzhou College of Technology and Business, Guangzhou, Guangdong 510850, \\ China \\ a Corresponding author: annylh2008@126.com
}

\begin{abstract}
By identifying the factors affecting the quality and safety in the supply chain of agricultural assets under the "Internet + ", the importance of customer needs and various needs is determined by using the analytic hierarchy process and questionnaire method. Combining HACCP system with QFD principle, a quality house of agricultural assets based on quality and safety control is drawn up. The quality and safety control system of agricultural assets is established by quantifying quality and safety prevention and control measures. Through the quantitative analysis of measures adopted, the operability and emphasis of the measures are strengthened, which can provide reference and basis for improving the quality and safety of agricultural assets in the new era in China.
\end{abstract}

\section{Introduction}

Agricultural materials, short for agricultural materials, generally refer to the material information and material conditions used to change and influence the labor object in the process of agricultural production, such as agricultural transportation machinery, production and processing machinery, pesticides, seeds, fertilizers, agricultural films. When agricultural materials are applied to agricultural production, advanced agricultural technology must be adopted to make them play a greater role, including scientific use of chemical fertilizer, prevention and control of diseases and insect pests, adoption of modern technology to change soil and farmland, and establishment of scientific farming system [1-3]. Crop seeds are the basis of agricultural production. Through seed selection, treatment, processing and storage, seeds with good quality are selected and passed on from generation to generation. Therefore, the continuous improvement of crop seed quality not only increases the output of crops, but also improves the quality of crops, improves the drought resistance and cold resistance of crops, expands the planting scope of crops. High quality crop seeds are the important material basis for the sustainable development of agriculture, improves the insect resistance and disease resistance of crops, and reduces the damage of crops. Loss, improve the current situation of China's food shortage, while improving the quality of life of the people [4].

Due to the low Internet penetration, the agricultural material industry has become a new blue ocean of e-commerce. With the application of new technologies and methods, new risks will also arise. Agricultural material products are the source of the supply chain of agricultural products, and also a very important part. At present, the research on the quality and safety of agricultural assets has not been involved. Therefore, under the opportunity of Internet + , agricultural assets It is an important research direction in the future to conduct a more systematic and in-depth study on product quality and safety and to build a quality and safety control system for agricultural products to adapt to the development of the new era $[5,6]$. According to the changes of the supply chain system of agricultural 
products brought about by "Internet +", this paper determines the customer demand and weight of the quality and safety control of agricultural products through the analytic hierarchy process, formulates preventive measures, establishes the evaluation dimensions and standards of the supply quality of agricultural products in view of the problems in the quality and safety control of agricultural products, strengthens the focus and operability of the measures, and constructs the HACCP system based on it. And QFD quality and safety control system of agricultural products.

\section{Description of agricultural products and formulation of flow chart}

\subsection{Establish HACCP system team}

According to the internal structure of agricultural material suppliers and combined with their own actual situation, the HACCP system team was established and participated by all members.

\subsection{Description of agricultural products by classification}

Taking crop seeds as an example, the classification, product characteristics, quality standards, shelf life and storage conditions of crop seeds were studied. The packaging materials, transportation methods and requirements as well as the expected users shall be listed one by one, and the basic situation description of agricultural products shall be made. In the production and management of seeds, the evaluation criteria of seed quality mainly refer to four indexes of seed purity, purity, water content and germination rate [7]. General crop seeds are composed of embryo, endosperm and seed coat. During identification, observe whether the internal structure, hardness, softness, looseness and color are consistent[8]. Storage conditions include facilities requirements, time requirement, distance requirements, water requirements and temperature requirements.

\subsubsection{Facilities requirements}

The warehouse shall be equipped with temperature and humidity display instruments, with airtight and ventilation performance, and be able to prevent humidity, mixing, rat and lark, insect and fire; the low-temperature seed warehouse shall meet the national and industrial design standards, with facilities to control temperature and humidity [9].

\subsubsection{Time requirement}

Use the seed warehouse to store and keep the seeds for more than three months, so as to keep the germination rate as high as possible.

\subsubsection{Distance requirements}

Store according to the type and variety of crops, and the warehouse shall be equipped with ventilation facilities to keep dry; The minimum height of seeds from the ground shall be $\geq 200 \mathrm{~mm}$, and the example of seeds from the wall shall be $\geq 500 \mathrm{~mm}$; after seeds are stored, there shall be a channel with a width of $\geq 1000 \mathrm{~mm}$.

\subsubsection{Water requirements}

The water content of seeds during storage shall meet the national standards, and seeds with water content exceeding the national standards and the requirements for safe storage shall be turned over for drying or mechanical dehumidification. It is advisable to keep the water content of vegetable seeds at $7 \%-12 \%$.

\subsubsection{Temperature requirements}

The temperature difference between the seeds put into the low-temperature seed warehouse and the temperature in the warehouse shall be $\leq 5^{\circ} \mathrm{C}$, the seeds shall contact the ground, and the walls shall be insulated and padded, overhead, to ensure ventilation [10]. 


\subsection{Formulation and confirmation of flow chart}

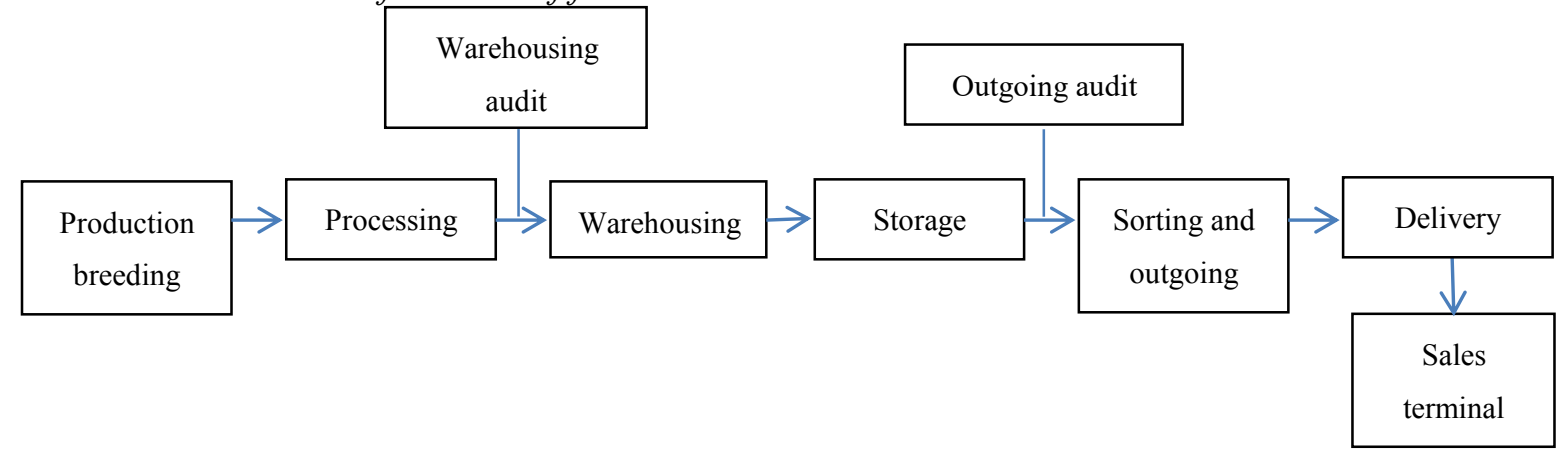

Figure1. Flow charts of various links of crop seeds

For crop seeds, traditional agricultural materials sales include at least four levels: manufacturers, county and city dealers, village and town retail stores and end users. The Internet + background is used to optimize the transaction chain, reduce the transaction and circulation links of crop seeds, so as to reduce the circulation cost and sales cost of crop seeds related enterprises, and improve the circulation efficiency of crop seeds [11-13]. The flow chart of each link of crop seeds developed by members of HACCP team is shown in Figure 1. There is no intermediate link such as seed distributor in the whole process.

Through the connection of Internet of things, it goes deep into the supply chain to serve the upstream and downstream enterprises of the industry, forming an information traceability chain of crop seeds.

\section{Construction of quality and safety control house for agricultural products}

The affinity graph method is used to determine customer needs, the 5M1E method is used to determine the quality and safety control indicators of crop seeds, and then calculate the importance of the quality and safety control indicators of crop seeds, so as to build a quality control house for agricultural products and formulate preventive measures.

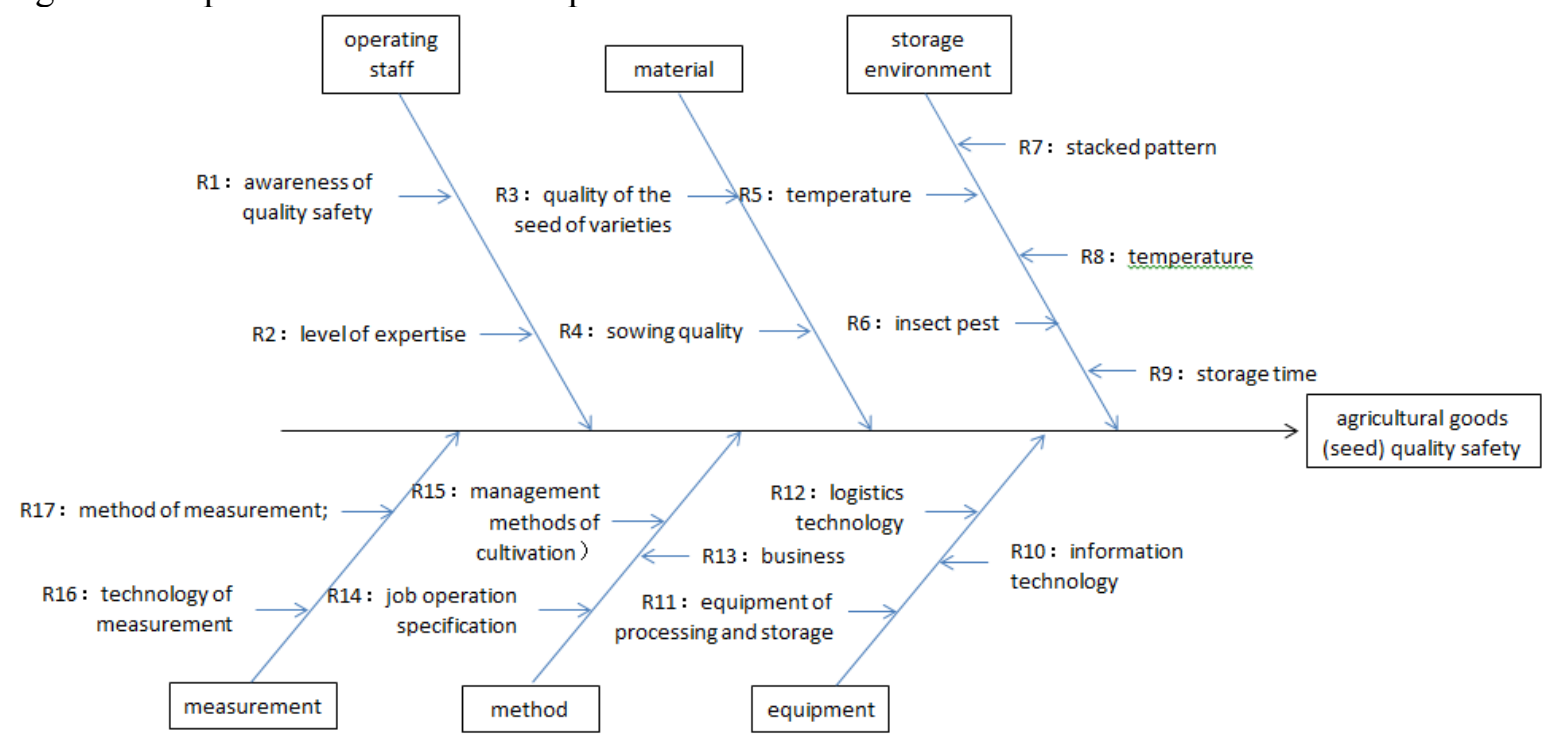

Figure 2. Quality and Safety Control Index Chart of Agricultural Assets

3.1 Determine the customer demand and weight for quality and safety control of agricultural materials

The collection and analysis of customer demand is the first step to determine the customer demand item. The customer survey interview and affinity chart method are used to classify, merge and map the 
items. The analytic hierarchy process is used to evaluate the importance of customer demand. Combined with the results of the questionnaire, the decision analysis software expert choice 2000 is used to analyze and calculate the data, so as to obtain the consumer demand of crop seed quality and safety control. Index [14-15], as shown in Table 1.

\subsection{Control indicators affecting the quality and safety of agricultural products}

In the production and breeding, processing, warehousing, storage, ex warehouse, distribution and sales of agricultural products, the fishbone diagram method is used to analyze operators, materials, storage environment, measurement, methods and equipment, and all relevant index parameters can be obtained, as shown in Figure 2.

\subsection{Construction of quality and safety control quality house for agricultural products}

Preventive measures for quality and safety control of agricultural products the framework elements of the house of quality are as follows: the left wall is the customer demand, the right wall is the customer demand, the ceiling is the quality and safety control index of agricultural products, the room is the relationship between customer demand and measure control index; the floor is the important component of quality and safety control index, and the basis is determined by combining questionnaire and AHP The importance of customer demand for quality and safety of agricultural products is shown in Figure 3.

Table 1. Consumer Demand and Importance of Quality and Safety Control of Agricultural Supply

\begin{tabular}{|c|c|c|c|c|}
\hline $\begin{array}{l}\text { Target } \\
\text { item }\end{array}$ & $\begin{array}{l}\text { First level } \\
\text { indicator }\end{array}$ & second level indicator & serial number & importance \\
\hline \multirow{6}{*}{$\begin{array}{l}\text { Customer } \\
\text { demand }\end{array}$} & $\begin{array}{c}\text { Seed quality } \\
\text { level }\end{array}$ & $\begin{array}{l}\text { purity } \\
\text { Cleanliness } \\
\text { Germination percentage } \\
\text { Water content }\end{array}$ & $\begin{array}{l}\text { C11 } \\
\text { C12 } \\
\text { C13 } \\
\text { C14 }\end{array}$ & $\begin{array}{l}0.1929 \\
0.1087 \\
0.3132 \\
0.0814\end{array}$ \\
\hline & $\begin{array}{l}\text { Strict control of } \\
\text { production and } \\
\text { breeding }\end{array}$ & $\begin{array}{l}\text { Production and processing } \\
\text { monitoring level } \\
\text { Standardization of the usage } \\
\text { of pesticide and fertilizer use } \\
\text { Field cultivation level }\end{array}$ & $\begin{array}{l}\mathrm{C} 21 \\
\mathrm{C} 22 \\
\mathrm{C} 23\end{array}$ & $\begin{array}{l}0.0876 \\
0.0523 \\
0.0276\end{array}$ \\
\hline & $\begin{array}{l}\text { Conformity of } \\
\text { storage } \\
\text { conditions }\end{array}$ & $\begin{array}{l}\text { Storage facility level } \\
\text { Warehouse inspection } \\
\text { strictness }\end{array}$ & $\begin{array}{l}\mathrm{C} 31 \\
\mathrm{C} 32\end{array}$ & $\begin{array}{l}0.0698 \\
0.0467\end{array}$ \\
\hline & $\begin{array}{l}\text { Distribution } \\
\text { service } \\
\text { reliability }\end{array}$ & $\begin{array}{l}\text { Delivery order satisfaction } \\
\text { rate } \\
\text { Vehicle cleanliness level } \\
\text { Distribution layout } \\
\text { rationality }\end{array}$ & $\begin{array}{l}\mathrm{C} 41 \\
\mathrm{C} 42 \\
\mathrm{C} 43\end{array}$ & $\begin{array}{l}0.1230 \\
0.0038 \\
0.0021\end{array}$ \\
\hline & $\begin{array}{l}\text { Professional } \\
\text { service } \\
\text { personnel }\end{array}$ & $\begin{array}{l}\text { Professional knowledge level } \\
\text { of service personnel } \\
\text { (cultivation guidance) } \\
\text { Ability to communicate } \\
\text { effectively with customers }\end{array}$ & C51 & 0.0275 \\
\hline & product price & $\begin{array}{l}\text { transportation cost } \\
\text { Price rationality }\end{array}$ & $\begin{array}{l}\text { C61 } \\
\text { C62 }\end{array}$ & $\begin{array}{l}0.0027 \\
0.0498\end{array}$ \\
\hline
\end{tabular}




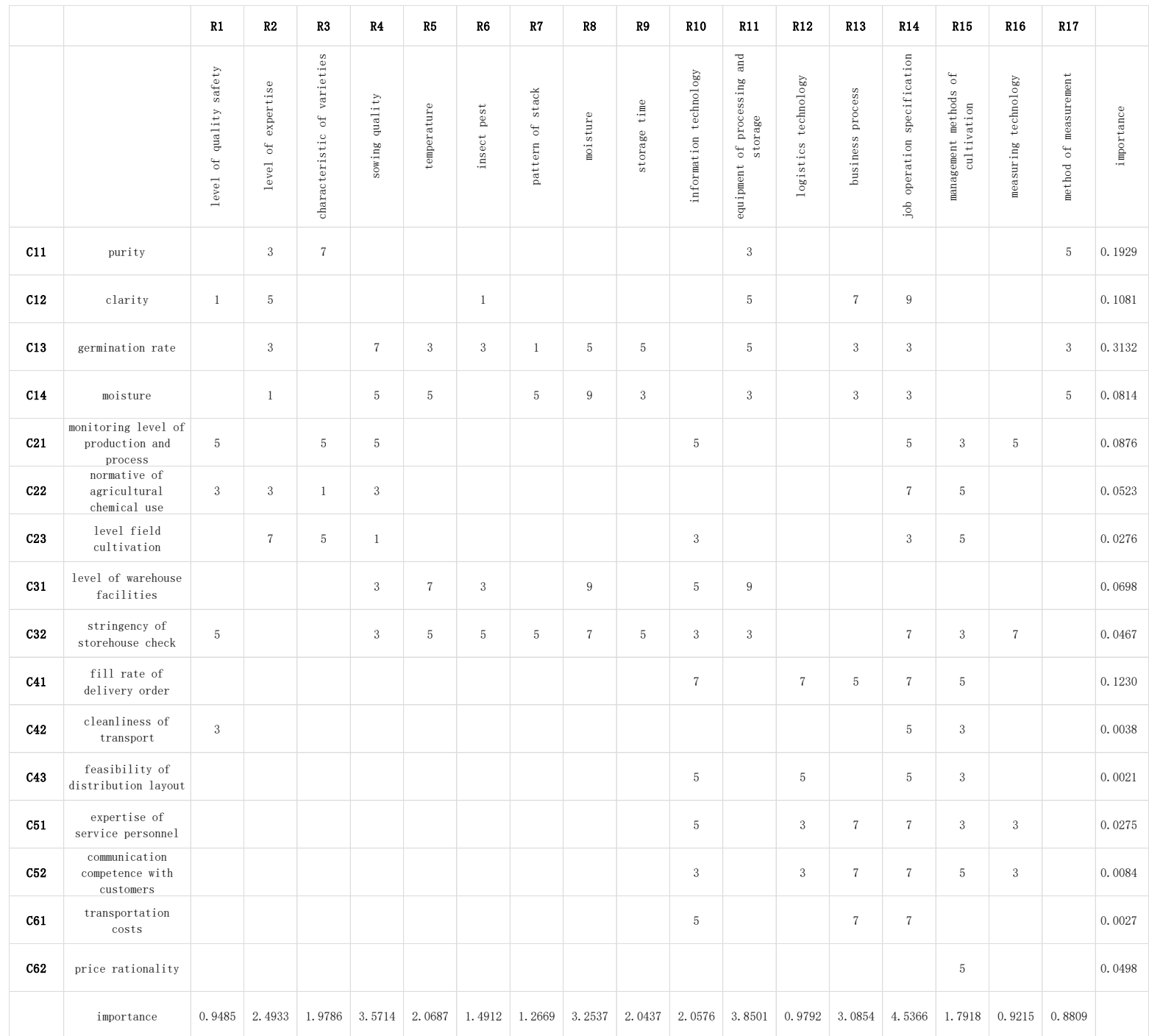

Figure 3. Quality and Safety Control House of Crop Seed

In the customer demand expansion table (C11-C62), the left wall is the customer demand; in the design element expansion table (R1-R17), the ceiling is the crop seed quality and safety control index; the room of the quality control house of agricultural products quality and safety control represents the interrelationship between the customer demand and the measure control index, and the number of each row and each column at the intersection represents the customer demand and the key control index. Level 1 is weak, level 3 is influential, level 5 is relatively close, level 7 is close, level 9 is very close, blank means there is no relationship)

\subsection{Formulate preventive measures}

The importance of the weighted quality and safety control indicators is ranked from high to low, and the indicators with high importance are mainly controlled. If the $\mathrm{j}$ preventive measures are related to multiple needs, these control indicators are more important, and the corresponding value is larger, that is to say, the preventive measures are more important. As can be seen from Figure 3, according to the order of importance from high to low, it can be concluded that operation specification (R14), processing and storage equipment (R11), sowing quality (R4), humidity (R8) and business process (R13) are important control indicators. Customers are most concerned about the germination rate of crop seeds. If they want to meet the needs of customers, they need to take corresponding measures, focusing on the control of the above indicators. 
Methods, equipment, materials and storage environment are several important factors, among which operation specifications and business processes belong to method elements, processing and storage equipment belong to equipment elements, sowing quality belongs to material elements, and humidity belongs to storage environment elements. To formulate preventive measures, we need to focus on the above four aspects. We need to formulate standardized field operation and processing operation for crop seeds, and design a set of reasonable and perfect business process. Processing and storage equipment is also one of the important factors, which needs regular maintenance and repair of processing and storage equipment. For crop seeds, we need to focus on improving their sowing quality. The high germination rate is closely related to the varieties of seeds and the planting and breeding process; the temperature and humidity control in the storage environment is the key, especially the humidity, which directly affects the quality of crop seeds. Advanced equipment is needed to monitor the environmental humidity in real time and transmit the data to relevant personnel through the Internet.

\section{Quality and safety control measures of agricultural products based on HACCP system}

\subsection{Prepare hazard analysis table of crop seed quality and safety control}

The hazard analysis form is completed by using Delphi method, questionnaire method and the construction of preventive measures house of quality.

\subsection{Determine critical control limits and HACCP schedule}

According to national standards, local standards and historical statistical data of enterprises, key limits are determined. Crop seed enterprises can complete monitoring procedures and implement them according to their own conditions to determine whether each control point meets the key limits, so as to formulate HACCP plan. The key limit value is based on the statistical data of the enterprise and the criteria of crop seed planting and processing. The monitoring method is the whole monitoring system. The corrective measures, records and verification are developed. The corrective measures are similar to the preventive measures. Finally, the HACCP schedule of crop seeds is obtained (as shown in Table 2).

Table 2. HACCP Schedule for Crop Seeds

\begin{tabular}{|c|c|c|c|c|c|c|c|c|}
\hline \multirow{2}{*}{$\begin{array}{l}\text { critical } \\
\text { control } \\
\text { point }\end{array}$} & \multirow{2}{*}{$\begin{array}{l}\text { Significan } \\
\text { t harm }\end{array}$} & \multirow{2}{*}{$\begin{array}{c}\text { Critical } \\
\text { control } \\
\text { limit }\end{array}$} & \multicolumn{3}{|c|}{ monitoring } & \multirow{2}{*}{$\begin{array}{l}\text { Rectification } \\
\text { measures }\end{array}$} & \multirow{2}{*}{ Record } & \multirow{2}{*}{ Verification } \\
\hline & & & Object & method & personnel & & & \\
\hline $\begin{array}{c}\text { CCP1 } \\
\text { production } \\
\text { and } \\
\text { breeding }\end{array}$ & $\begin{array}{l}\text { Chemical: } \\
\text { chemical } \\
\text { fertilizer, } \\
\text { pesticide, } \\
\text { heavy } \\
\text { metal in } \\
\text { soil, etc. }\end{array}$ & $\begin{array}{l}\text { Agricultur } \\
\text { al and } \\
\text { drug } \\
\text { residues } \\
\text { below the } \\
\text { maximum } \\
\text { limit }\end{array}$ & $\begin{array}{l}\text { Harmful } \\
\text { chemicals } \\
\text { and } \\
\text { detection } \\
\text { rate }\end{array}$ & $\begin{array}{l}\text { Chemical } \\
\text { test } \\
\text { method } \\
\text { and metal } \\
\text { detector } \\
\text { method }\end{array}$ & $\begin{array}{l}\text { Quality } \\
\text { inspector }\end{array}$ & $\begin{array}{c}\text { Fail to go to the } \\
\text { next step }\end{array}$ & $\begin{array}{l}\text { Records of } \\
\text { fertilization } \\
\text { and pesticide } \\
\text { use }\end{array}$ & $\begin{array}{l}\text { Inspection } \\
\text { record }\end{array}$ \\
\hline $\begin{array}{c}\mathrm{CCP2} \\
\text { processing }\end{array}$ & $\begin{array}{l}\text { Biological: } \\
\text { pathogens, } \\
\text { mites }\end{array}$ & $\begin{array}{l}\text { Microbial } \\
\text { content } \\
\text { not } \\
\text { exceeding } \\
\text { MRLs }\end{array}$ & $\begin{array}{l}\text { Pathogenic } \\
\text { microorga } \\
\text { nism } \\
\text { content }\end{array}$ & $\begin{array}{l}\text { Microbiol } \\
\text { ogical } \\
\text { test }\end{array}$ & $\begin{array}{l}\text { Quality } \\
\text { inspector }\end{array}$ & $\begin{array}{l}\text { Sampling } \\
\text { inspection }\end{array}$ & $\begin{array}{l}\text { Equipment } \\
\text { management } \\
\text { report }\end{array}$ & $\begin{array}{l}\text { Inspection } \\
\text { records and } \\
\text { visual } \\
\text { inspection }\end{array}$ \\
\hline $\begin{array}{c}\text { CCP3 } \\
\text { warehousi } \\
\text { ng and } \\
\text { storage }\end{array}$ & $\begin{array}{l}\text { Biological: } \\
\text { pathogenic } \\
\text { microorgan } \\
\text { ism, mould } \\
\text { and insect } \\
\text { pest }\end{array}$ & $\begin{array}{l}\text { No insect } \\
\text { damage } \\
\text { and mould } \\
\text { content } \\
\text { not } \\
\text { exceeding } \\
\text { the } \\
\text { maximum } \\
\text { limit }\end{array}$ & $\begin{array}{l}\text { Pest and } \\
\text { mould spot }\end{array}$ & $\begin{array}{l}\text { Microbiol } \\
\text { ogical } \\
\text { test }\end{array}$ & $\begin{array}{l}\text { Quality } \\
\text { inspector }\end{array}$ & $\begin{array}{l}\text { Kill pests and } \\
\text { diseases, } \\
\text { control } \\
\text { appropriate } \\
\text { temperature and } \\
\text { humidity, and } \\
\text { prevent mildew }\end{array}$ & $\begin{array}{l}\text { Warehousing } \\
\text { inspection } \\
\text { report and } \\
\text { warehouse } \\
\text { inspection } \\
\text { record }\end{array}$ & $\begin{array}{l}\text { Inspection } \\
\text { records and } \\
\text { regular } \\
\text { inspection }\end{array}$ \\
\hline
\end{tabular}




\begin{tabular}{|c|c|c|c|c|c|c|c|c|}
\hline $\begin{array}{c}\text { CCP4 } \\
\text { sorting } \\
\text { and } \\
\text { delivery }\end{array}$ & $\begin{array}{c}\text { Physical: } \\
\text { foreign } \\
\text { matter }\end{array}$ & $\begin{array}{c}\text { Product } \\
\text { packaging } \\
\text { is intact }\end{array}$ & $\begin{array}{c}\text { Degree of } \\
\text { packing }\end{array}$ & $\begin{array}{c}\text { Metal } \\
\text { detector } \\
\text { method }\end{array}$ & $\begin{array}{c}\text { Quality } \\
\text { inspector }\end{array}$ & $\begin{array}{c}\text { Monitor the } \\
\text { process of } \\
\text { delivery and } \\
\text { delivery to } \\
\text { ensure no } \\
\text { impurities are } \\
\text { mixed in }\end{array}$ & $\begin{array}{c}\text { Product } \\
\text { delivery } \\
\text { report, } \\
\text { delivery note } \\
\text { and unloading } \\
\text { record }\end{array}$ & $\begin{array}{c}\text { Inspection } \\
\text { records and } \\
\text { visual } \\
\text { inspection }\end{array}$ \\
\hline
\end{tabular}

In the process of production and breeding, chemical hazards are main, biological hazards are main in the process and storage, and physical hazards are main in the sorting and delivery. In the production and breeding of crop seeds, rational application of chemical fertilizer, strict specification and control of pesticide use, attention to ensure the safety of soil use, to prevent heavy metal pollution; in the processing of agricultural products, mainly the possible pathogenic bacteria and mite pollution on the processing line, sampling inspection shall be carried out to ensure that the microbial content does not exceed the maximum residue limit; crop seeds In terms of warehousing and storage, it is mainly mold breeding and pest invasion in the storage process. Mold is mainly controlled by adjusting the temperature and humidity in the storage environment, and pest can be prevented and controlled by corresponding insecticides or preventive measures. In terms of sorting out, transportation and distribution, it is necessary to strengthen the inspection of packaging tightness to avoid bag inflation, package damage and foreign matters mixing. The occurrence of harm.

\section{Verification and feedback}

\subsection{Establish verification and record keeping procedures}

Taking crop seeds as an example, the records include field cultivation management records, pesticide and fertilizer use records, management reports, production and processing monitoring records, warehousing inspection indexes and records of agricultural products, warehousing inspection indexes and records of agricultural products, health status records, dynamic data records of temperature and humidity, delivery records, etc. Check and verify the above records regularly.

\subsection{Effect feedback, evaluation and improvement}

Through the establishment of the above quality and safety pre control system for agricultural products, in the process of implementation, relevant experts are organized to evaluate the effect of the system, which can be evaluated from three aspects: operation effect, operation difficulty and overall investment. According to the evaluation results, the system is continuously improved and optimized in combination with PDCA ring.

\section{Conclusion}

Agriculture plays an important role in China's economic development, social stability and the improvement of people's living standards, and improved varieties are the most important material basis for agricultural production. As a traditional agricultural country, China has always attached great importance to the safety of agricultural products. Generations passed on the selection method of crop seeds to future generations. High quality crop seeds are an important material basis for the sustainable development of agriculture, reducing the loss of crops and improving the output of crops [16-18]. Based on the principles of HACCP and QFD, this paper establishes the quality and safety pre control system of agricultural products, and combines the qualitative and quantitative analysis to establish the evaluation index and latitude of agricultural supply, so as to make the quality and safety evaluation and control of agricultural products more operable.

\section{Acknowledgments}

This work was supported by Higher Vocational Education Research Association of China (zjyjh2017-37); Special subject of construction and management of laboratory (training) of Guangzhou College of Technology and Business in 2019 (2019-014); National Innovation and 
Entrepreneurship Training Program for College Students 2018 (201813714002); National service industry standardization pilot project research on cold chain safety and standardization of green fruit and vegetable Airport (SACS [2016] No.6)

\section{References}

[1] C.H. Wang, Agric. Inf. China 21, 70(2016)

[2] J. Zhang, L Hu, J. Huazhong Agric. Univ. 31, 258(2012)

[3] G.G. Savaliram, H.L. Vinayak, D.N. Tukaram, J. Crop Sci. Biotechnol. 17, 11(2014)

[4] W. Wang, Y. Yuan, D. Nimazaxi, J. Wang, Z. Luo, Tibet J. Agric. Sci. 33, 24(2011)

[5] P. Zhang, Agric. Info. China 04, 124(2015)

[6] H. Liu Hua, J. Huang, W.D. Yu, Agric. Prod. Process. 16, 90(2018)

[7] W. Wang, Seed Technol. 34, 13(2016)

[8] Y. Luo, J. Liang, G. Zeng, X. Li, M. Chen, L. Jiang, W. Xing, N. Tang, Ecotoxicol. Environ. Saf. 184, 109597 (2019)

[9] H. Du, X. Zhang, Y. Fang, South. Agri. Mach. 47, 44(2016)

[10] Z. Xu, Seed Sci. Technol. 34, 39(2016)

[11] Y. Zhang, Seed Sci. Technol. 35, 40(2017)

[12] J. Hu, J. Li, H. Pang, ICEMSE 2019, (2019)

[13] J. Zhu, Anhui Agric. Univ., 25 (2017)

[14] H. Huo, S. Zhao, Preserv. Process. 17, 69(2017)

[15] J. Zhao, F. Jin, Agric. Technol. Promot. China 33(05), 6(2017)

[16] P. Wu, X. Jin, R. Su, Shanghai Agric. Sci. Technol. 04, 11(2012)

[17] C. Zhang, J. Dai, Anhui Agric. Bull. 17, 145(2011)

[18] H. Lu, L. Miu, R. Liu, China Seed Ind. 12, 22(2012) 